\title{
Investigation of the role of stereoelectronic effects in the conformation of piperidones by NMR spectroscopy and X-ray diffraction
}

\author{
Cesar Garcias-Morales, David Ortegón-Reyna and Armando Ariza-Castolo*
}

\author{
Full Research Paper \\ Address: \\ Departamento de Química, Centro de Investigación y de Estudios \\ Avanzados del Instituto Politécnico Nacional, Avenida Instituto \\ Politécnico Nacional 2508 Colonia San Pedro Zacatenco, C.P. 07360 , \\ México, D.F., Mexico \\ Email: \\ Armando Ariza-Castolo* - aariza@cinvestav.mx \\ * Corresponding author \\ Keywords: \\ NMR spectroscopy; piperidone; spin-spin coupling constant; \\ stereoelectronic effect; $X$-ray diffraction structure \\ Beilstein J. Org. Chem. 2015, 11, 1973-1984. \\ doi:10.3762/bjoc. 11.213 \\ Received: 22 July 2015 \\ Accepted: 01 October 2015 \\ Published: 22 October 2015 \\ Associate Editor: J. A. Murphy \\ (c) 2015 Garcias-Morales et al; licensee Beilstein-Institut. \\ License and terms: see end of document.
}

\begin{abstract}
This paper reports the synthesis of a series of piperidones $\mathbf{1 - 8}$ by the Mannich reaction and analysis of their structures and conformations in solution by NMR and mass spectrometry. The six-membered rings in 2,4,6,8-tetraphenyl-3,7-diazabicyclo[3.3.1]nonan9-ones, compounds 1 and 2, adopt a chair-boat conformation, while those in 2,4-diphenyl-3-azabicyclo[3.3.1]nonan-9-ones, compounds 3-8, adopt a chair-chair conformation because of stereoelectronic effects. These stereoelectronic effects were analyzed by the ${ }^{1} J_{\mathrm{C}-\mathrm{H}}$ coupling constants, which were measured in the ${ }^{13} \mathrm{C}$ satellites of the ${ }^{1} \mathrm{H}$ NMR spectra obtained with the hetero-dqf pulse sequence. In the solid state, these stereoelectronic effects were investigated by measurement of X-ray diffraction data, the molecular geometry (torsional bond angles and bond distances), and inter- and intramolecular interactions, and by natural bond orbital analysis, which was performed using density functional theory at the $\omega \mathrm{B} 97 \mathrm{XD} / 6311++\mathrm{G}(\mathrm{d}, \mathrm{p})$ level. We found that one of the main factors influencing the conformational stability of 3-8 is the interaction between the lone-pair electrons of nitrogen and the antibonding sigma orbital of $\mathrm{C}(7)-\mathrm{H}_{\mathrm{eq}}\left(\mathrm{n}_{\mathrm{N}} \rightarrow \sigma^{*} \mathrm{C}-\mathrm{H}(7)\right.$ eq $)$, a type of hyperconjugative interaction.
\end{abstract}

\section{Introduction}

Stereoelectronic effects have attracted the attention of many researchers with an interest in organic chemistry because of the major role that conformation plays in molecules and biomolecules; in addition, such effects are related to the spatial orientation of the orbital [1-3], which determines the stability of a structure and its reactivity $[4,5]$. One of the most important stereoelectronic effects is hyperconjugation, which is related to the anomeric effect (effect where a heteroatomic substituent adjacent to a heteroatom within a cyclohexane ring prefers the axial orientation instead of the equatorial) [6-12]. 
Moreover, stereoelectronic effects have been related to the stabilization of carbanions [13,14], carbocations [15-18], and free radicals [19-21] which has been explained by negative $\left(n_{X} \rightarrow \sigma^{*}{ }_{C-Y}\right)$ or positive hyperconjugation $\left(\sigma_{C-Y} \rightarrow \pi^{*}\right.$ or $\left.p\right)$.

Hyperconjugation is commonly described as the interaction between electronic orbitals where one filled orbital (donor) interacts with another unfilled orbital (acceptor) with the presence of an additional resonance structure (double-bond/no-bond resonance (Figure 1a). This interaction is also accompanied by stabilization of the molecule (Figure 1b) [1-3].
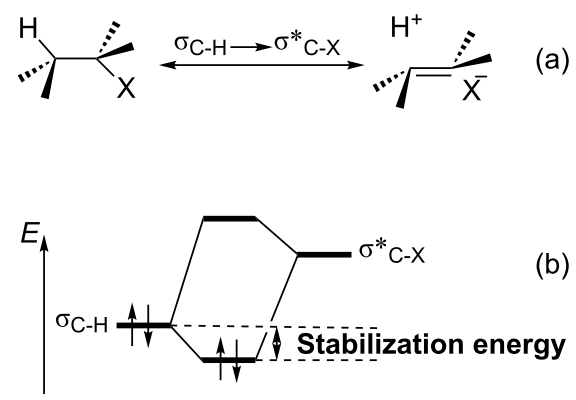

Figure 1: (a) Schematic representation of the vicinal $\sigma_{C-H} \rightarrow \sigma^{*} \mathrm{C}-\mathrm{X}$ interaction by double-bond/no-bond resonance. (b) Stabilization energy because of the hyperconjugative interaction between $\sigma_{\mathrm{C}-\mathrm{H}}$ and $\sigma^{*} \mathrm{C}-\mathrm{X}$ orbitals.

There is evidence that the interaction between electronic orbitals filled orbital (donor) with another unfilled orbital (acceptor) can be observed several bonds away from the orbitals. This effect is classified as hyperconjugation (electronic delocalization placing a $\sigma$-bridge between a donor and an acceptor orbital, Figure 2a), homohyperconjugation, considered the result of the direct through-space interactions between donor and acceptor orbitals is observed when a saturated center intervenes (the phenomenon is called $\gamma$-effect when the acceptor is a cationic p-orbital, Figure 2b), homoanomeric effect (when the acceptor is a $\sigma^{*}$-orbital and the donor is a lone pair), and double hyperconjugation (extends the delocalization range even further by placing a $\sigma$-bridge between a donor and an acceptor, Figure 2c) [22-27].

In the six-membered saturated heterocycles the more stable conformation is the one where the substituent on the $\beta$-carbon is equatorial with respect to the heteroatom, this is known as homoanomeric effect, which is a type of homohyperconjugation [28-36]. The homoanomeric effect can be observed in two cases: the first-one through a W-arrangement, where the lonepair electrons (LPEs) of $\mathrm{O}, \mathrm{N}$, and $\mathrm{S}$, on the pseudo equatorial position interact with the antibonding $\sigma$ orbital $\left(n_{X} \rightarrow \sigma^{*} C \beta-Y\right)$ and the second-one is the Plough effect, where the lone-pair

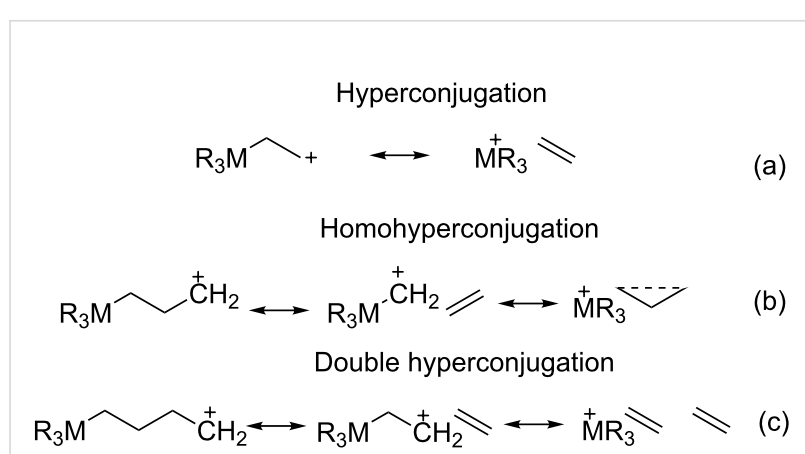

Figure 2: Schematic representation of stereoelectronic effects (a) hyperconjugation, (b) homohyperconjugation, (c) double hyperconjugation.

electrons (LPEs) of $\mathrm{O}, \mathrm{N}$, and $\mathrm{S}$, on the pseudo axial position interact with the antibonding $\sigma$ orbital $\left(\mathrm{n}_{X} \rightarrow \sigma^{*} \mathrm{C} \beta-\mathrm{Y}\right)$ Figure 3 [22,37-44].

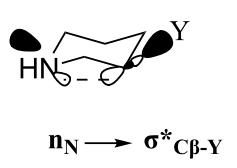

$\mathrm{W}$ arrangement

(a)

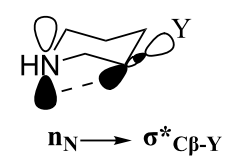

Plough effect

(b)
Figure 3: Schematic representation of possible homoanomeric interactions in six-membered saturated heterocycles. (a) Homohyperconjugation through the $\mathrm{W}$ arrangement, (b) homohyperconjugation through the Plough effect.

For the study of this kind of interaction, the NMR technique is a useful tool as it is a highly sensitive spectroscopical method, and NMR spin-spin coupling constants are used to experimentally investigate stereoelectronic effects [6-12,30-36,42,43]. In particular, it is acknowledged that delocalization interactions from electrons have a relatively important Fermi contact contribution [45]. For example in cyclohexane the spin-scalar coupling constant of the equatorial hydrogen $\left(\mathrm{H}_{\mathrm{eq}}\right)$ is $4 \mathrm{~Hz}$ higher $\left({ }^{1} J_{\mathrm{C}, \mathrm{Heq}}\right)$ than the axial one $\left({ }^{1} J_{\mathrm{C}, \mathrm{Hax}}\right)$. This difference in the ${ }^{1} J_{\mathrm{C}, \mathrm{H}}$ values has been explained in terms of delocalization interactions from electron hyperconjugation.

This study describes the synthesis of a series of 2,4-diphenyl-3azabicyclo[3.3.1] nonan-9-one compounds (Figure 4) with restricted conformations. The complete analysis of the chemical shifts and the indirect coupling constants gives information about the electronic density and the interaction through space between the LPE of nitrogen with the antibonding $\sigma * \mathrm{C}(7)-\mathrm{Heq}$ orbital $\left(\mathrm{n}_{\mathrm{N}} \rightarrow \sigma^{*} \mathrm{c}_{(7)-\mathrm{Heq}}\right)$, the results are supported by natural bond orbital (NBO) analysis. 


\begin{tabular}{|c|c|c|c|c|c|c|c|}
\hline & Comp. & $\bar{X}$ & $\mathrm{Ar}$ & $\mathbf{R}^{1}$ & $\mathbf{R}^{2}$ & $\mathbf{R}^{3}$ & $\mathbf{R}^{4}$ \\
\hline & 1 & $\mathrm{NH}$ & $\mathrm{C}_{6} \mathrm{H}_{5}$ & $\mathrm{H}$ & $\mathrm{H}$ & $\mathrm{C}_{6} \mathrm{H}_{5}$ & $\mathrm{C}_{6} \mathrm{H}_{5}$ \\
\hline & 2 & $\mathrm{NH}$ & $\mathrm{C}_{6} \mathrm{H}_{5}$ & $\mathrm{H}$ & $\mathrm{CH}_{3}$ & $\mathrm{C}_{6} \mathrm{H}_{5}$ & $\mathrm{C}_{6} \mathrm{H}_{5}$ \\
\hline 4 & 3 & $\mathrm{CH}_{2}$ & $\mathrm{C}_{6} \mathrm{H}_{5}$ & $\mathrm{H}$ & $\mathrm{H}$ & $\mathrm{H}$ & $\mathrm{H}$ \\
\hline & 4 & $\mathrm{CH}_{2}$ & $\mathrm{C}_{6} \mathrm{H}_{5}$ & $\mathrm{H}$ & $\mathrm{CH}_{3}$ & $\mathrm{H}$ & $\mathrm{H}$ \\
\hline & 5 & $\mathrm{CH}_{2}$ & $\mathrm{C}_{6} \mathrm{H}_{5}$ & $\mathrm{CH}_{3}$ & $\mathrm{CH}_{3}$ & $\mathrm{H}$ & $\mathrm{H}$ \\
\hline & 6 & $\mathrm{CH}_{2}$ & $3 \mathrm{NO}_{2}-\mathrm{C}_{6} \mathrm{H}_{4}$ & $\mathrm{H}$ & $\mathrm{H}$ & $\mathrm{H}$ & $\mathrm{H}$ \\
\hline $8 \times \widehat{6} R^{4}$ & 7 & $\mathrm{CH}_{2}$ & $3 \mathrm{NO}_{2}-\mathrm{C}_{6} \mathrm{H}_{4}$ & $\mathrm{H}$ & $\mathrm{CH}_{3}$ & $\mathrm{H}$ & $\mathrm{H}$ \\
\hline & 8 & $\mathrm{CH}_{2}$ & $3 \mathrm{NO}_{2}-\mathrm{C}_{6} \mathrm{H}_{4}$ & $\mathrm{CH}_{3}$ & $\mathrm{CH}_{3}$ & $\mathrm{H}$ & $\mathrm{H}$ \\
\hline
\end{tabular}

Figure 4: Structure of compounds 1 to 8 .

\section{Results and Discussion}

The 2,4-diphenyl-3-azabicyclo[3.3.1] nonan-9-ones were synthesized by the Mannich reaction [46-49]. As shown in Scheme 1; 1 and $\mathbf{2}$ were synthesized using ammonium acetate, benzaldehyde, and acetone or 2-butanone (4:4:1), respectively [50-52].

When we probed this reaction with 3-pentanone, the product was 3,5-dimethyl-2,6-diphenylpiperidin-4-one, while the reaction with 2-butanone gave 2 and 3-methyl-2,6-diphenylpiperidin-4-one in a ratio of 9:1 (Scheme S2, Supporting Information File 1).

Piperidones have previously been prepared using ammonium acetate, benzaldehyde, and cyclohexanone for $\mathbf{3}$, ammonium acetate, benzaldehyde, and 2-methylcyclohexanone for $\mathbf{4}$, and ammonium acetate, benzaldehyde, and 2,6-dimethylcyclohexanone for 5 in a 2:2:1 ratio Scheme 1 [53-56].

According to Scheme 1, two possible diastereomers could be obtained for 3-8: both phenyl groups are in a cis orientation and both phenyl groups in a trans orientation. However, only the diastereomer with the phenyl groups in the cis orientation was obtained. This is because in the transition state (TS) for the $c i s$ compounds the energy of the $1 \mathrm{H}, 3 \mathrm{H}$-allylic strain $\left(\mathrm{A}^{1,3}\right)$ is lower in comparison with the TS trans, $1 \mathrm{Ar}, 3 \mathrm{H}$-allylic strain [57], which is caused by the hindrance effect of the phenyl group on $\mathrm{C}(1)$ with the proton on $\mathrm{C}(3)$.

The new compounds $\mathbf{6}-\mathbf{8}$ (Scheme 2) were synthesized by the reaction between ammonium acetate, $m$-nitrobenzaldehyde, and cyclohexanone for $\mathbf{6}$, ammonium acetate, $m$-nitrobenzaldehyde, and 2-methylcyclohexanone for 7, and ammonium acetate, $m$-nitrobenzaldehyde, and 2,6-dimethycyclohexanone for $\mathbf{8}$.

The proposed reaction mechanism for piperidone formation is through an aldimine, which is formed by the reaction between an aldehyde and ammonium acetate. The aldimine is then attacked by a keto-enol to form a $\beta$-aminocarbonyl, which reacts with another molecule of aldehyde to form a second aldimine. Finally, 6-endo-enol-endo intramolecular cyclization leads to piperidone formation (Scheme 2) $[58,59]$.<smiles>[R]c1cccc(C=O)c1</smiles>

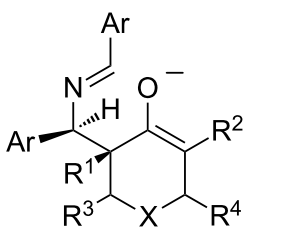

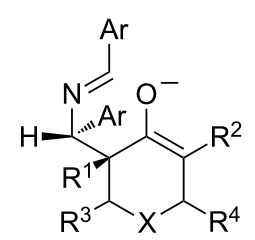

favored disfavored

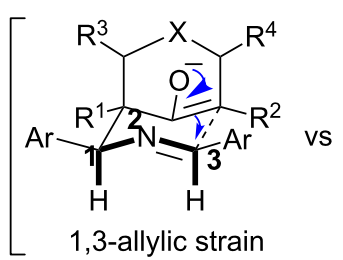

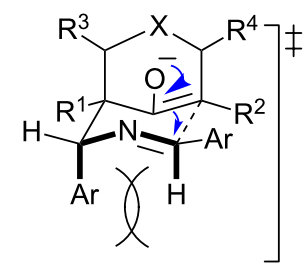

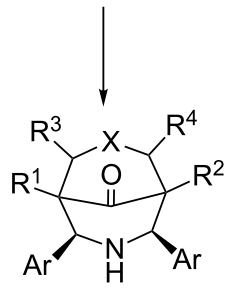

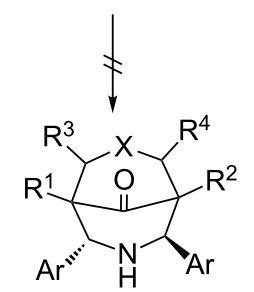




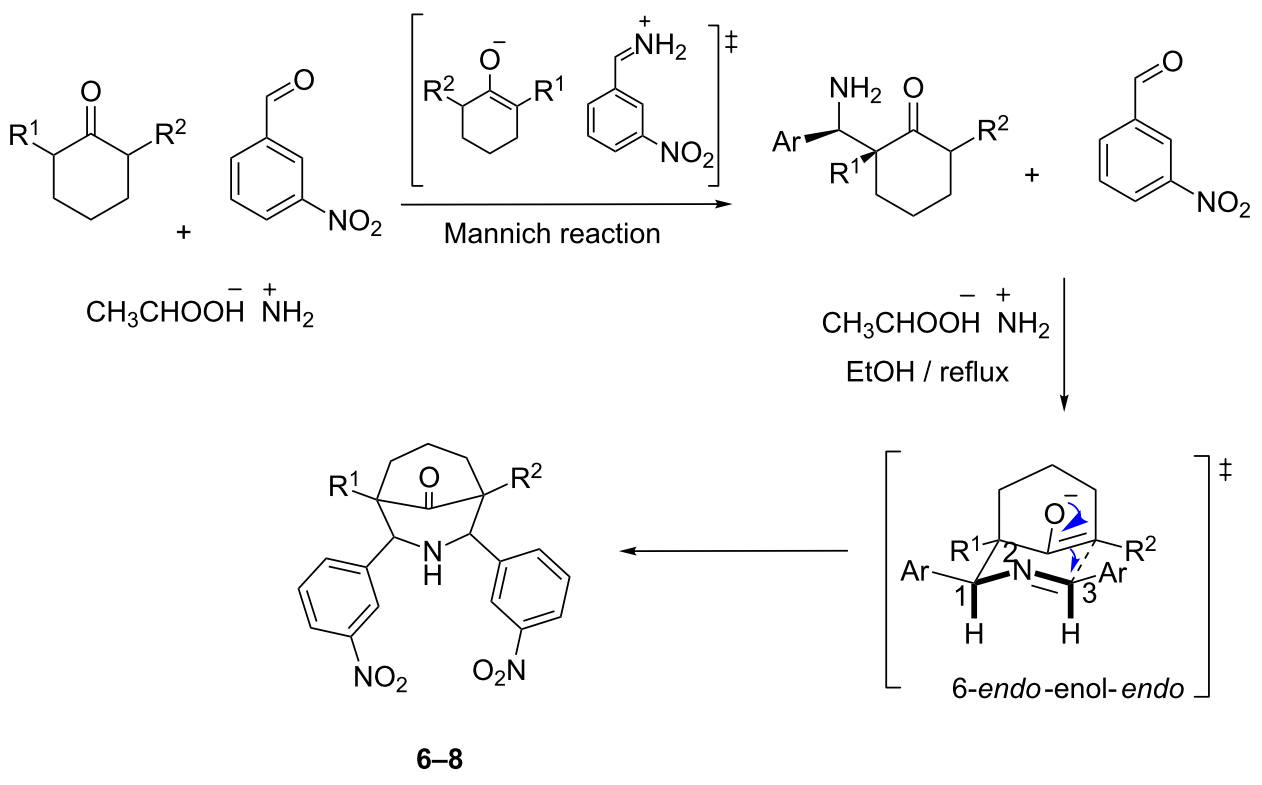

Scheme 2: For $6, R^{1}=R^{2}=H$, for $7, R^{1}=H, R^{2}=C H_{3}$, for $8, R^{1}=R^{2}=C H_{3}$.

\section{Structural and conformational analysis of piperidones $\mathbf{1 - 8}$ by NMR and X-ray diffraction}

Solution characterization of $\mathbf{1 - 8}$ was performed by ${ }^{1} \mathrm{H}$ and ${ }^{13} \mathrm{C} \mathrm{NMR}$, and mass spectrometry. The $\mathrm{H}, \mathrm{H}$ and $\mathrm{H}, \mathrm{C}$ connectivities were determined by COSY and HSQC experiments, while the conformation was determined by nOe through t-ROESY experiments.

Figure 5 shows the ${ }^{1} \mathrm{H}$ NMR spectrum of $\mathbf{1}$. Three signals are present in the aliphatic region: $\mathrm{H}(2,4)_{\mathrm{ax}}$ protons as a double signal at $\delta=4.37, \mathrm{H}(6,8)_{\text {ax }}$ protons as a doublet at $\delta=4.72$, and $\mathrm{H}(1,5)_{\text {eq }}$ protons shifted to $\delta=2.87$. The $\mathrm{H}, \mathrm{H}$ coupling constants are $2.1 \mathrm{~Hz}$ for ${ }^{3} J_{\mathrm{H}(1) \mathrm{eq}, \mathrm{H}(2) \text { ax }}$ and $3.0 \mathrm{~Hz}$ for ${ }^{3} J_{\mathrm{H}(1) \text { eq,H(8)ax}}$. In the ${ }^{13} \mathrm{C}$ NMR spectrum, three aliphatic signals are present at $61.80,63.41$, and $58.77 \mathrm{ppm}$, which correspond to $\mathrm{C} 8, \mathrm{C} 1$, and $\mathrm{C} 2$, respectively. A signal corresponding to the carbonyl carbon is located at $211.66 \mathrm{ppm}$.

Figure 5a shows the conformations of $\mathbf{1}$, determined by the t-ROESY experiment. In solution, one of the six-membered rings is in the chair conformation, while the second is in the boat conformation to prevent repulsion between the LPEs of the nitrogen.

Although 3, 5, 6, and 8 have four stereogenic centers, however, there is a mirror plane that passes through $\mathrm{N}(3), \mathrm{C}(9)$, and $\mathrm{C}(7)$, so these compounds do not exhibit optical activity. Compounds 4 and 7 have a methyl group on the $\mathrm{C}(1)$ carbon, where there is no mirror plane, thereby making $\mathbf{4}$ and $\mathbf{7}$ asymmetric and they were obtained as racemic mixtures. In the ${ }^{1} \mathrm{H}$ NMR spectrum of 4 (Figure 6), $\mathrm{H}(4)_{\mathrm{ax}}$ is located at $\delta=4.40$, with a ${ }^{3} J_{\mathrm{H}, \mathrm{H}}$ coupling of $3.0 \mathrm{~Hz}$ with $\mathrm{H}(5)_{\mathrm{eq}}$, which is shifted to $\delta=2.57$. $\mathrm{H}(2)_{\mathrm{ax}}$ is present as a singlet at $\delta=3.95, \mathrm{H}(6)_{\mathrm{ax}}, \mathrm{H}(7)_{\mathrm{ax}}$, and $\mathrm{H}(8)_{\mathrm{ax}}$ are located at $\delta=1.71,3.19$, and $1.46 \mathrm{ppm}$, respectively, while $\mathrm{H}(6)_{\mathrm{eq}}$ and $\mathrm{H}(7)_{\mathrm{eq}}$ are located at $\delta=1.94$ and 1.45 , respectively, and $\mathrm{H}(8)_{\mathrm{eq}}$ shifted to $\delta=2.08 . \mathrm{H}(6)_{\mathrm{ax}}$ and $\mathrm{H}(8)_{\mathrm{ax}}$ shifted to lower frequencies than $\mathrm{H}(6)_{\mathrm{eq}}$ and $\mathrm{H}(8)_{\mathrm{eq}}$ with $\Delta \delta=\mathrm{H}(6)_{\mathrm{eq}}-$ $\mathrm{H}(6)_{\mathrm{ax}}=0.23$, while $\Delta \delta=\mathrm{H}(8)_{\mathrm{eq}}-\mathrm{H}(8)_{\mathrm{ax}}=0.62 . \mathrm{H}(7)_{\mathrm{ax}}$ is shifted to higher frequency than $\mathrm{H}(7)_{\mathrm{eq}}$ with $\Delta \delta=\mathrm{H}(7)_{\mathrm{eq}}-$ $\mathrm{H}(7)_{\mathrm{ax}}=-1.74$. Table $\mathrm{S} 1$ (Supporting Information File 1) lists the proton chemical shifts and ${ }^{n} J_{\mathrm{H}, \mathrm{H}}$ coupling constants.

The H,C-HSQC spectrum of $\mathbf{4}$ shows that C(1), C(2), and C(4) shifted to $\delta=50.94,71.33$, and 65.06 , respectively, while $\mathrm{C}(5)$, $\mathrm{C}(6), \mathrm{C}(7)$, and $\mathrm{C}(8)$ shifted to $\delta=54.49,29.23,21.54$, and 36.96 , respectively. The carbonyl carbon is located at $218.01 \mathrm{ppm}$. Table S2 (Supporting Information File 1) lists all of the ${ }^{13} \mathrm{C}$ chemical shifts and ${ }^{1} J_{\mathrm{C}, \mathrm{H}}$ values. The conformation of the piperidones was determined in solution through nOe (Figure 6a). In 4, nOe was observed among $\mathrm{H}(4)_{\mathrm{ax}}, \mathrm{H}(5)_{\mathrm{eq}}$, and $\mathrm{H}(2)_{\mathrm{ax}}$, and for $\mathrm{H}(7)_{\mathrm{ax}}$ with $\mathrm{H}(6)_{\mathrm{eq}}$ and $\mathrm{H}(8)_{\mathrm{eq}}$. Furthermore, nOe was observed among $\mathrm{H}(5)_{\mathrm{eq}}, \mathrm{H}(6)_{\mathrm{ax}}$, and $\mathrm{H}(6)_{\mathrm{eq}}$ (Figure 6b). Based on the nOe values and ${ }^{3} J_{\mathrm{H}, \mathrm{H}}$ coupling constants, the solution conformation was determined using the Karplus curve [60]. For 4-8, the six-membered rings exhibit the chair-chair conformation, with both of the phenyl rings in equatorial positions. For $\mathbf{1}$ and $\mathbf{2}$, the six-membered rings exhibit the 
(a)

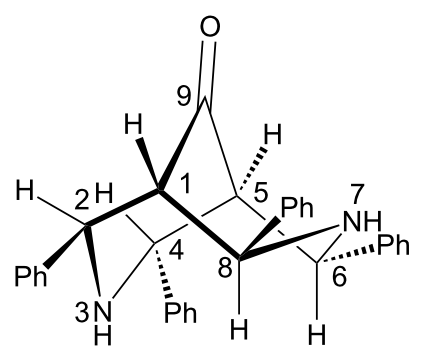

(b)

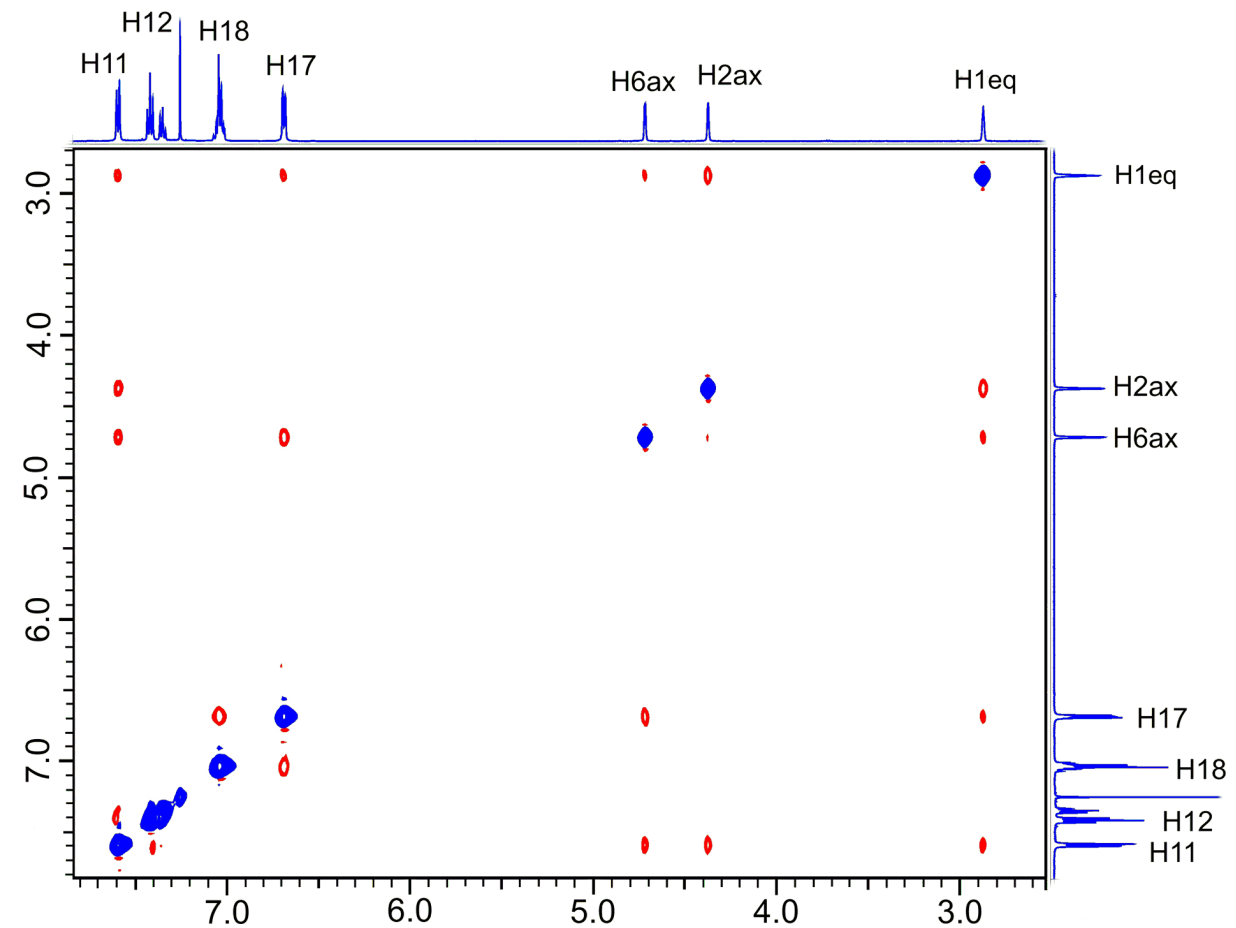

Figure 5: (a) Favored conformation for compound 1, determined by nOe effect, (b) t-ROESY spectrum of 1 recorded at $500 \mathrm{MHz}^{\text {in }} \mathrm{CDCl}_{3}$.

chair-boat conformation, because one nitrogen atom is substituted by a methyl group. As a result, LPE repulsion is absent in compounds 3-8.

The solid-state conformations of the piperidones were determined by X-ray diffraction (XRD). Crystals of 1, 3, 5, 6, and 7 suitable for XRD were obtained. The crystal structures of $\mathbf{3}$ and 5 have been previously reported [47,61-63]. The crystal structures of $\mathbf{1}, \mathbf{6}$, and $\mathbf{7}$ are reported for the first time. Crystals of $\mathbf{1}$ were obtained by slow evaporation of a saturated toluene solution, and 1 crystallized in the $P 2_{1} / n$ space group. The sixmembered ring in the crystal structure exhibits a chair-boat conformation.
For 1, the crystal structure shows that the aromatic rings on the six-membered ring with the boat conformation are antiperiplanar to the aromatic ring on the six-membered ring with the chair conformation (Figure 7a). This geometry allowed a $\mathrm{C}-\mathrm{H} \cdots \pi$ intramolecular interaction between the aromatic rings. There are also $\mathrm{C}-\mathrm{H} \cdots \pi$ intermolecular interactions [61-63]. Two intermolecular hydrogen bonds are observed for $\mathrm{N}(3)-\mathrm{H}(3) \cdots \mathrm{O}(1)$ (Figure 7b). One hydrogen bond has a N(3) nitrogen donor (D) on molecule 1 and a carbonyl acceptor (A) on molecule 2 . In the second hydrogen bond, the carbonyl on molecule 1 (A) interacts with a nitrogen N(3) (D) of molecule 3, forming chains of molecules. The $\mathrm{D} \cdots \mathrm{A}$ distance is 2.971(4), and the $\mathrm{N}(3)-\mathrm{H}(3) \cdots \mathrm{O}(1)$ angle is $131^{\circ}$. 
(a)

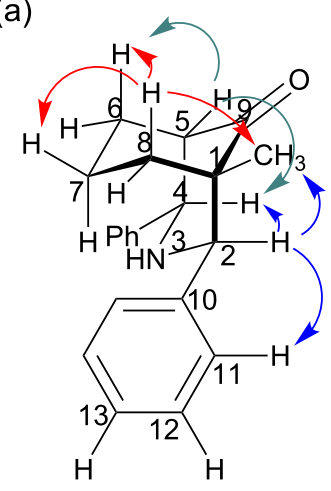

(b)

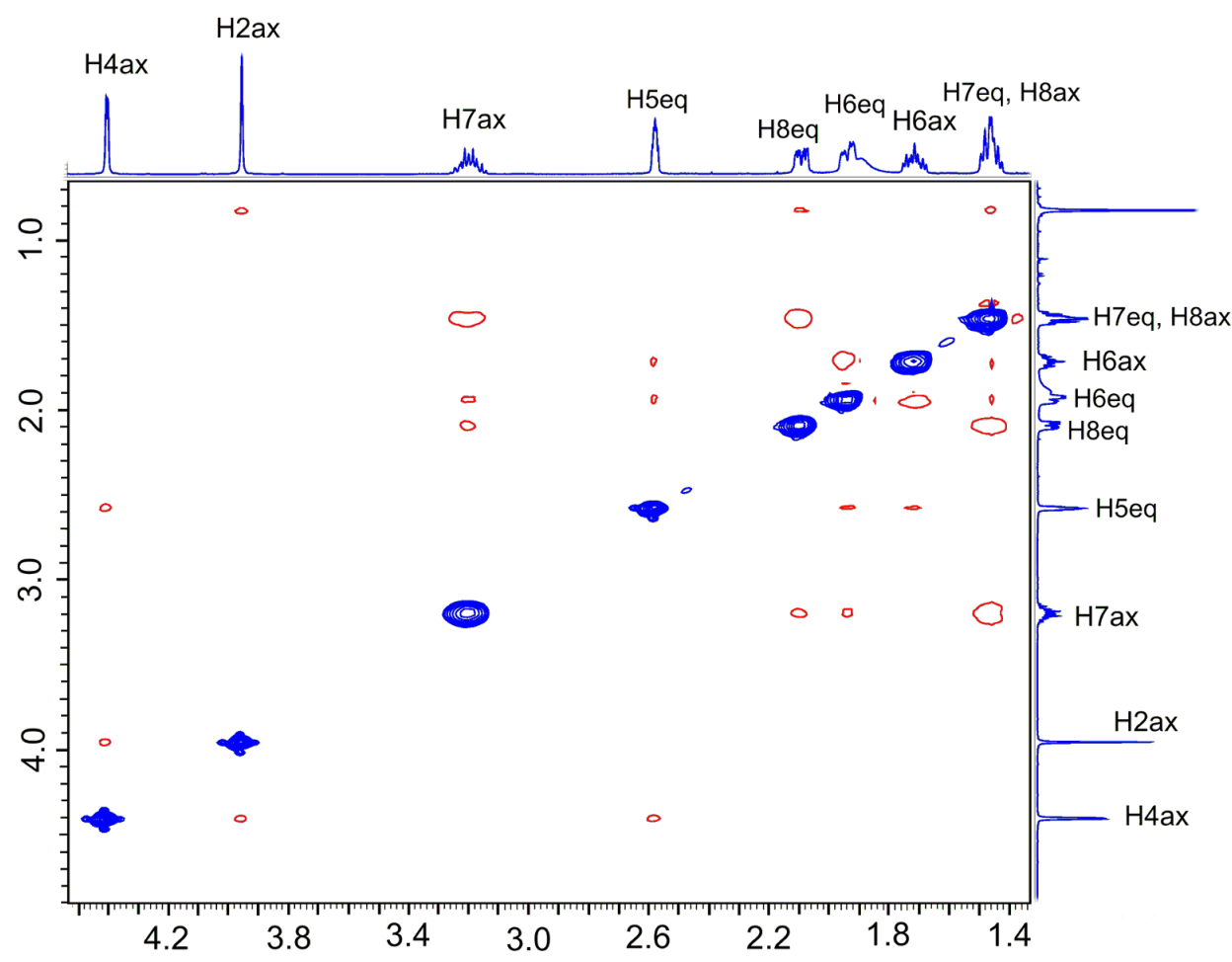

Figure 6: (a) Preferred conformation of 4 determined by nOe, (b) t-ROESY spectrum of 4 recorded at $500 \mathrm{MHz}^{\text {in }} \mathrm{CDCl}_{3}$.

Crystals of 6 were obtained by slow evaporation of a saturated acetone solution. The molecule crystallized in a triclinic crystal lattice with the $P-1$ space group. Crystals of 7 were obtained by slow evaporation of a saturated toluene solution. Compound 7 crystallized in an orthorhombic crystal lattice with the noncentrosymmetric space group Pna2 $2_{1}$. Hence, the molecule exhibits optical activity (Figure $8 \mathrm{a}$ ).

Figure $8 \mathrm{~b}$ shows the crystal structure of $\mathbf{6}$, where cycles formed through the intermolecular hydrogen bond $\mathrm{N}(3)-\mathrm{H}(3) \cdots \mathrm{O}(28)$. The D $\cdots$ A distance is $3.186(3) \AA$ and the $\mathrm{N}(3)-\mathrm{H}(3) \cdots \mathrm{O}(28)$ angle is $160 \pm 2^{\circ}$. Compound 7 formed chains of molecules by $\mathrm{N}(3)-\mathrm{H}(3) \cdots \mathrm{O}(22)$ hydrogen bonds with a $\mathrm{D} \cdots \mathrm{A}$ distance of $3.261(3) \AA$ and a $\mathrm{N}(3)-\mathrm{H}(3) \cdots \mathrm{O}(28)$ angle of $162 \pm 1^{\circ}$.

\section{Stereoelectronic effect analysis}

$\sigma \rightarrow \sigma^{*}, \sigma \rightarrow \pi^{*}, \mathrm{nx} \rightarrow \sigma^{*}, \mathrm{nx} \rightarrow \pi^{*}$, hyperconjugation, and homohyperconjugative interactions significantly affect the Fermi contact contribution to the scalar spin-spin coupling constant. Therefore, the $\mathrm{C}-\mathrm{H}$ coupling constants were used to investigate the stereoelectronic effects $[64,65]$. The main interactions found by NBO are listed in Supporting Information File 1. 
(a)

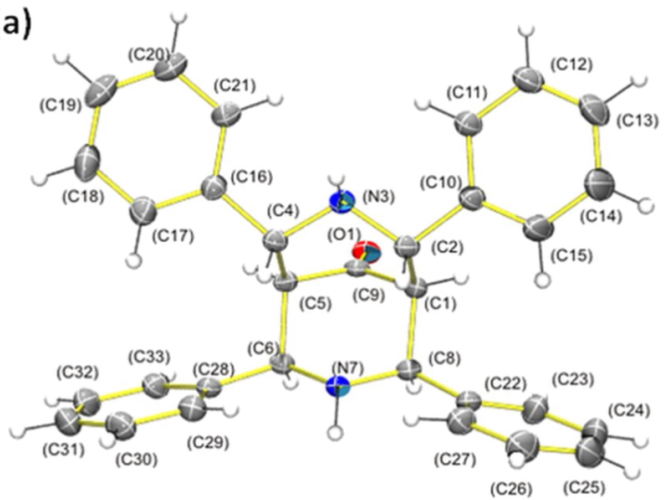

(b)

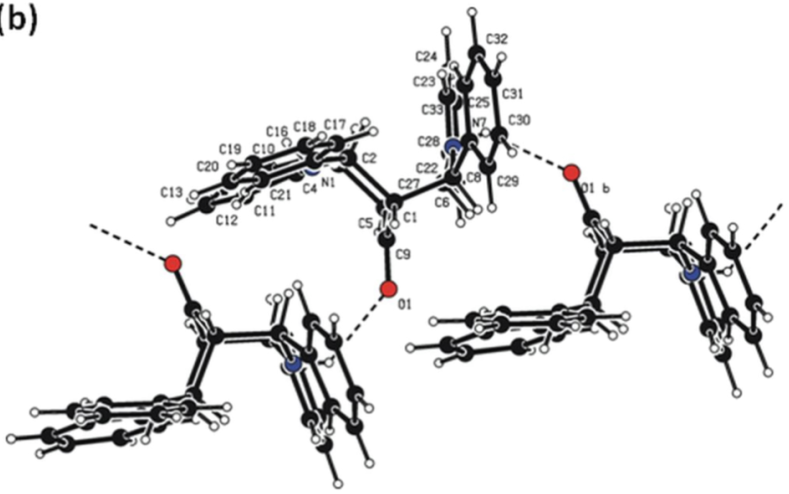

Figure 7: (a) ORTEP diagram of 1 . The thermal ellipsoids are drawn at the $30 \%$ probability level for all atoms other than $\mathrm{H}$. (b) $\mathrm{Crystal}$ packing and $\mathrm{N}(3)-\mathrm{H}(3) \cdots \mathrm{O}(1)$ intermolecular hydrogen bonds of 1 .

(a)

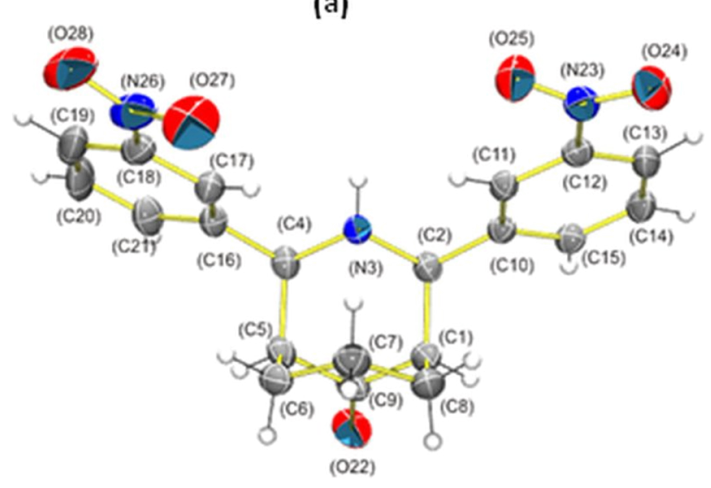

6

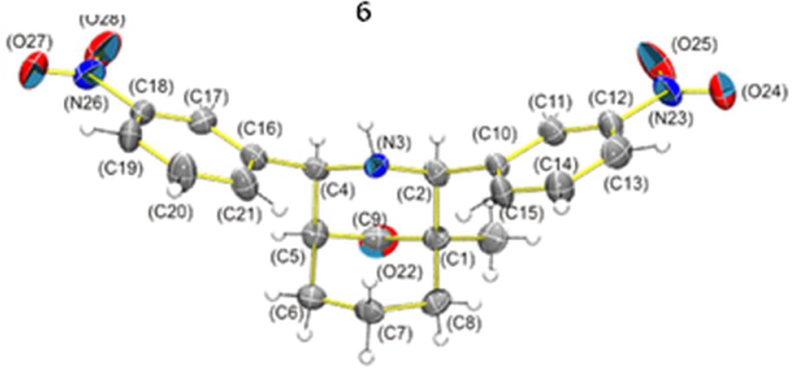

7

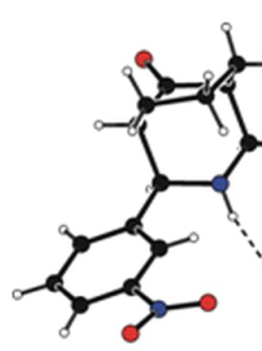

(b)

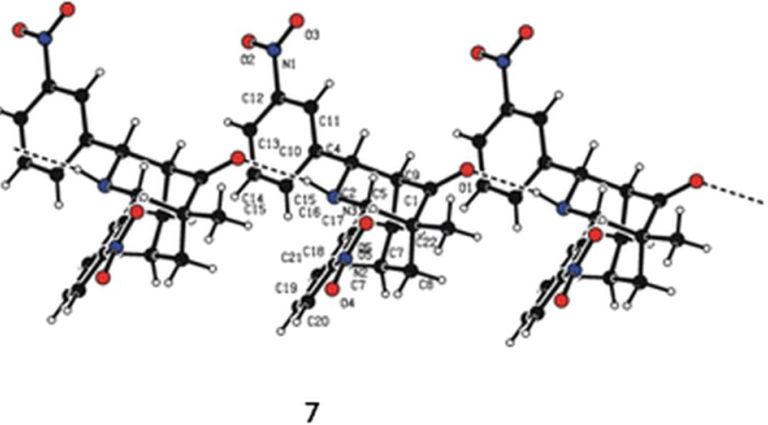

Figure 8: (a) ORTEP diagrams of 6 and 7. The thermal ellipsoids are drawn at the $30 \%$ probability level for all atoms other than $\mathrm{H}$. (b) $\mathrm{N}(3)-\mathrm{H}(3) \cdots \mathrm{O}(28)$ intermolecular hydrogen bonds of 6 and $\mathrm{N}(3)-\mathrm{H}(3) \cdots \mathrm{O}(22)$ intermolecular hydrogen bonds of 7 .

Hyperconjugation and homohyperconjugation in piperidones were investigated by analyzing the ${ }^{1} J_{\mathrm{C}, \mathrm{H}}$ coupling constants, which were measured in the ${ }^{13} \mathrm{C}$ satellites in the ${ }^{1} \mathrm{H}$ NMR spectrum obtained with dqf-heteronuclear pulse sequence [66,67]. Figure 9 a shows the ${ }^{1} J_{\mathrm{C}, \mathrm{H}}$ coupling constants for $\mathbf{3}, \mathbf{5}, \mathbf{6}$, and $\mathbf{8}$, as well as the coupling constant difference between axial and equatorial protons. The $\Delta^{1} J_{\mathrm{C}, \mathrm{H}}$ values $\left({ }^{1} J_{\mathrm{C}, \mathrm{Heq}}{ }^{-1} J_{\mathrm{C}, \mathrm{Hax}}\right)$ for the proton on the $\beta$-carbon with respect to the carbonyl group for $\mathbf{3}$, $\mathbf{5}, \mathbf{6}$, and $\mathbf{8}$ are $4.4,5.1,8.0$, and $6.5 \mathrm{~Hz}$, respectively. The $\Delta^{1} J_{\mathrm{C}, \mathrm{H}}$ coupling constant difference for cyclohexane is $3.9 \mathrm{~Hz}$. There is a linear relationship between the ${ }^{1} J_{\mathrm{C}, \mathrm{H}}$ value and the population analysis using the SCF density (Figure 9b), which was estimated for compound $\mathbf{3}$.

The $\Delta^{1} J_{\mathrm{C}, \mathrm{H}}\left(={ }^{1} J_{\mathrm{C}, \mathrm{H}(7) \text { eq }}-{ }^{1} J_{\mathrm{C}, \mathrm{H}(7) \mathrm{ax}}\right)$ value for compound $\mathbf{8}$ is $-5.0 \mathrm{~Hz}$, and the $\Delta^{1} J_{\mathrm{C}, \mathrm{H}}$ values for $3-7$ are $-5.6,-5.8,-5.7$, 


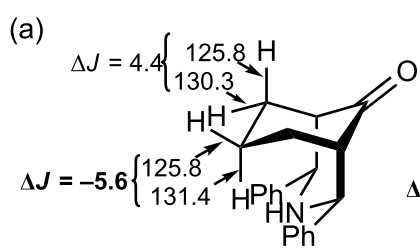

3

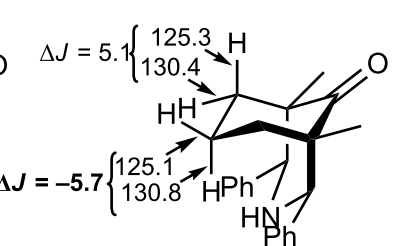

5

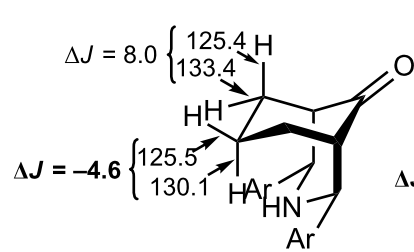

6

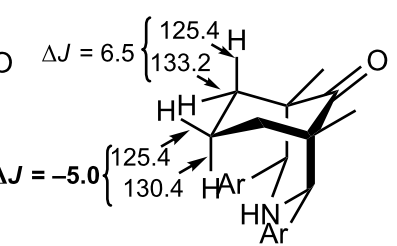

8

(b)

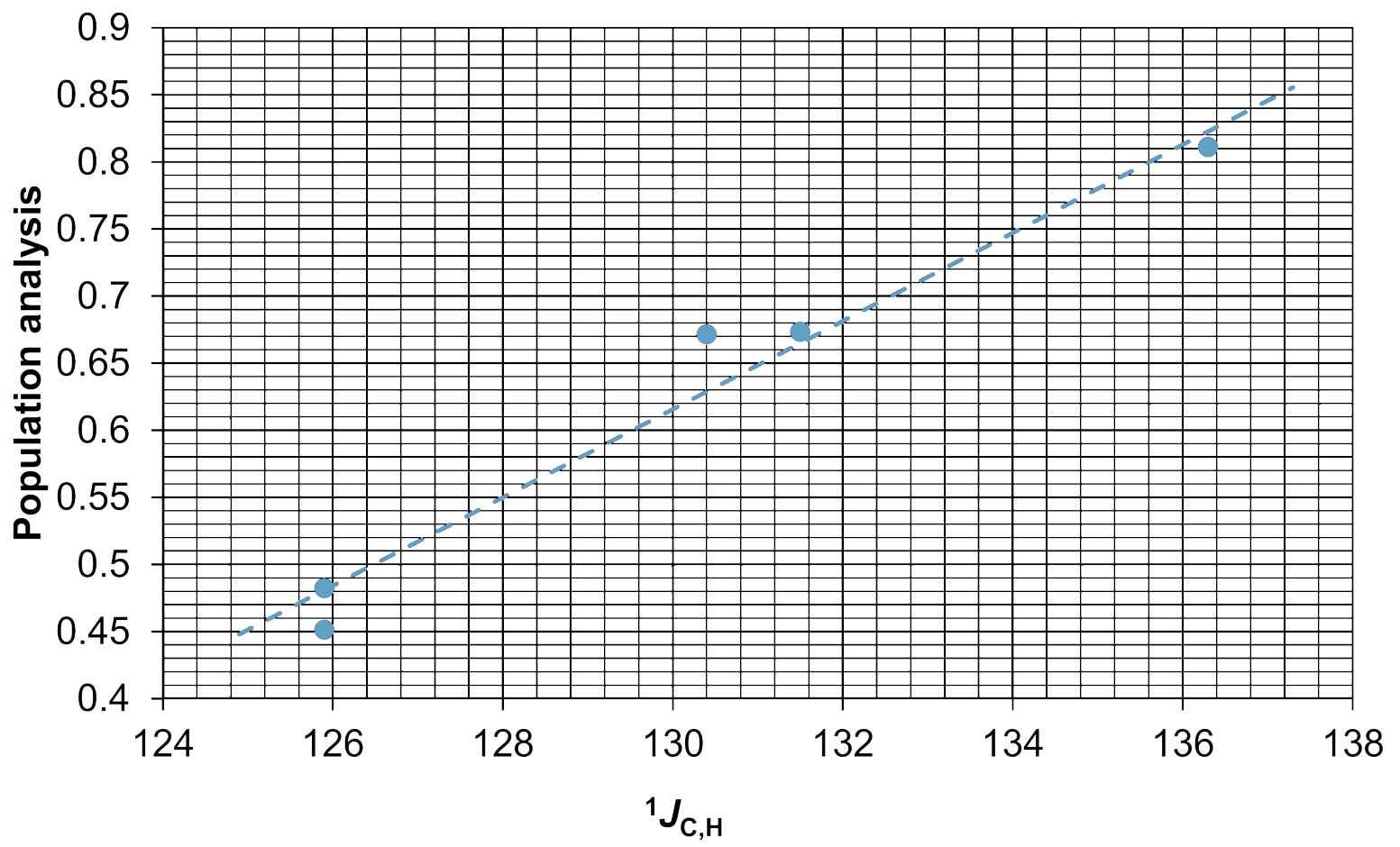

Figure 9: (a) ${ }^{1} J_{\mathrm{C}, \mathrm{H}}$ coupling constant of 3, 5, 6, and 8. (b) Plot of the population analysis versus ${ }^{1} J_{\mathrm{C}, \mathrm{H}}\left(\right.$ slope $=0.0329$ and $\left.R^{2}=0.9748\right)$.

-4.6 , and $-3.6 \mathrm{~Hz}$, respectively. The negative sign of the $\Delta^{1} J_{\mathrm{C}, \mathrm{H}}$ coupling constant difference suggests that there is an effect that changes the ${ }^{1} J_{\mathrm{C}, \mathrm{H}}$ values. This effect is related to the proximity and geometrical relation between the LPE of nitrogen and the antibonding $\sigma$ orbital $\mathrm{C}-\mathrm{H}(7)_{\mathrm{eq}}$. The hyperconjugative interaction $\mathrm{n}_{\mathrm{N}} \rightarrow \sigma^{*} \mathrm{C}-\mathrm{H}(7)$ eq is the effect that alters the ${ }^{1} J_{\mathrm{C}, \mathrm{H}}$ values, causing a change in the Fermi contact term (Scheme 3). This interaction was determined in compound $\mathbf{3}$ by second-order perturbation theory analysis of the Fock matrix in the NBO basis $(0.55 \mathrm{kcal} / \mathrm{mol})$.

In the crystal structures of $\mathbf{3}, \mathbf{5}, \mathbf{6}$, and 7 , the geometric relationship between the LPE of nitrogen and the antibonding $\sigma$ orbital $\mathrm{C}-\mathrm{H}(7)_{\text {eq }}$ promotes the $\mathrm{n}_{\mathrm{N}} \rightarrow \sigma_{\mathrm{C}-\mathrm{H}(7) \text { eq }}$ interaction, which is caused by the $\mathrm{N}(3)-\mathrm{C}(7)-\mathrm{H}_{\mathrm{eq}}$ angle being near $160^{\circ}$ (Table 1 ). Furthermore, the $\mathrm{N}(3) \cdots \mathrm{C}(7)$ distance was measured, and it is close to $2.9 \AA$ (Figure 10). The distance determined from a $\omega \mathrm{B} 97 \mathrm{XD} / 6-311++\mathrm{G}(\mathrm{d}, \mathrm{p})$ calculation of $\mathbf{3}$ is $2.96 \AA$. This value

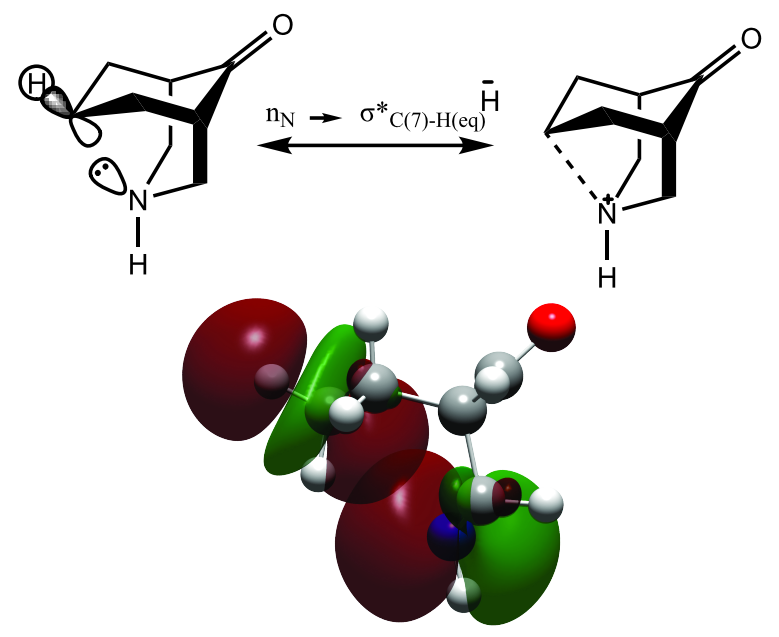

Scheme 3: Representation of the $n_{N} \rightarrow \sigma^{*} C-H(7)$ eq interaction. The interaction energy is $0.55 \mathrm{kcal} / \mathrm{mol}$ at the $\omega B 97 X D / 6-311++G(d, p)$ level. 
is in agreement with $\mathrm{n}_{\mathrm{N}} \rightarrow \sigma_{\mathrm{C}-\mathrm{H}(7) \text { eq }}$ hyperconjugation. Hence, the chair-chair conformation in $\mathbf{3}-\mathbf{8}$ is preferred over the chair-boat conformation in $\mathbf{1}$ and $\mathbf{2}$.

\begin{tabular}{|c|c|c|}
\hline Comp. & $D(\AA)$ & angles of $\mathrm{N}(3) \cdots \mathrm{C}(7) \cdots \mathrm{H}(7)_{\text {eq }}$ \\
\hline 3 & 2.935 & 159.24 \\
\hline 5 & 2.907 & 161.65 \\
\hline 6 & 2.935 & 159.85 \\
\hline 7 & 2.913 & 159.85 \\
\hline
\end{tabular}

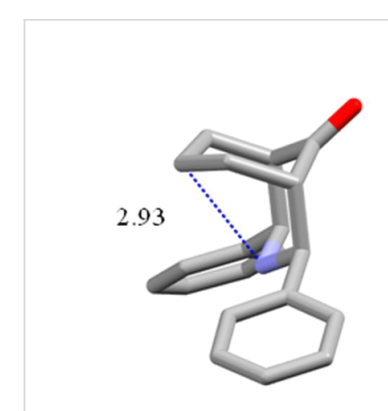

3

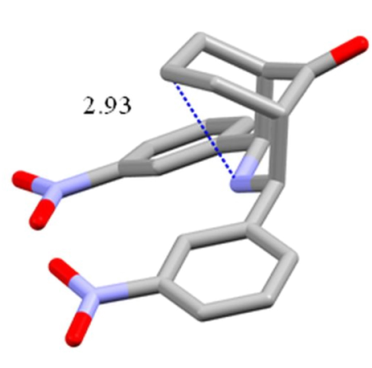

6

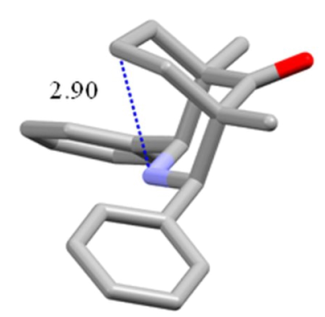

5

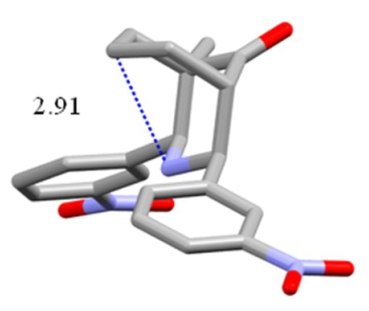

7
Figure 10: Distances between $\mathrm{N}(3)$ and $\mathrm{C}(7)$ for $3,5,6$, and 7 measured in the structures obtained by XRD.

\section{Conclusion}

The six-membered rings in $\mathbf{1}$ and $\mathbf{2}$ prefer the chair-boat conformation because that conformation minimizes repulsion between the LPEs of both nitrogen atoms. Moreover, the sixmembered rings of 3-8 exhibit the chair-chair conformation because of the substitution of the nitrogen atom by the methylene group $\left(\mathrm{CH}_{2}\right)$.

The ${ }^{1} J_{\mathrm{C}, \mathrm{H}}$ coupling constants measured by ${ }^{1} \mathrm{H}$ NMR show a linear relationship with the electron density by NBO analysis. The chemical shift difference between $\mathrm{H}(7)_{\mathrm{ax}}$ and $\mathrm{H}(7)_{\mathrm{eq}}$ is
$1.7 \pm 0.3 \mathrm{ppm}$, with $\mathrm{H}(7)_{\mathrm{ax}}$ shifted to a higher frequency. The

${ }^{1} J_{\mathrm{C}, \mathrm{Heq}}$ coupling constant is $4.7 \pm 1.1 \mathrm{~Hz}$ lower than the ${ }^{1} J_{\mathrm{C}, \mathrm{Hax}}$ coupling constant because of homohyperconjugation between the LPE of nitrogen and the $\mathrm{C}-\mathrm{H}(7)_{\mathrm{eq}}$ antibonding $\sigma$ orbital $\left(\mathrm{n}_{\mathrm{N}} \rightarrow \sigma^{*} \mathrm{C}(7)-\mathrm{Heq}\right)$. This interaction indicates that the $\mathrm{H}(7)_{\mathrm{ax}}$ and $\mathrm{H}(7)_{\text {eq }}$ chemical shift difference is because of the $\mathrm{n}_{\mathrm{N}} \rightarrow \sigma^{*} \mathrm{C}(7)-\mathrm{Heq}$ interaction: the electronic density in the $\mathrm{C}-\mathrm{H}(7)_{\mathrm{eq}}$ bond increases and shields the proton. Moreover, this information is supported by the X-ray diffraction structures, in which the measured $\mathrm{C}(7)-\mathrm{N}(3)$ distance and geometric disposition of the $\mathrm{N}(3)-\mathrm{C}(7)-\mathrm{H}_{\mathrm{eq}}$ angle suggest that the homohyperconjugative interaction is important for the preferred conformations of 2,4-diphenyl-3-azabicyclo[3.3.1]nonan-9-ones.

\section{Experimental \\ Spectra}

The NMR spectra of $\mathbf{1}-\mathbf{8}$ were recorded at $21 \pm 1{ }^{\circ} \mathrm{C}$ using a Jeol ECA 500 spectrometer equipped with a $5 \mathrm{~mm}$ multinuclear pulse-field gradient probe. All of the spectra were recorded in $\mathrm{CDCl}_{3}$ solution $(0.9 \mathrm{mmol}$ of the compound per $0.5 \mathrm{~mL}$ solvent). The chemical shifts were referenced to tetramethylsilane $\left(\mathrm{CH}_{3}\right)_{4} \mathrm{Si}$, which served as an internal standard $\left(\delta^{1} \mathrm{H}=0\right.$, $\left.\delta^{13} \mathrm{C}=0\right)$.

${ }^{1} \mathrm{H}$ NMR spectra were recorded at $500.159 \mathrm{MHz}$ using a spectral width of $9384.3 \mathrm{~Hz}$, acquisition time of $6.98 \mathrm{~s}$, 65536 points, 512 scans, and a recycle delay of $1 \mathrm{~s}$. Fourier transformation was applied using an exponential function (line width $=0.2$ ). ${ }^{13} \mathrm{C}$ satellites were directly determined from the ${ }^{1} \mathrm{H}$ NMR spectra or using the same spectral condition as the heteronuclear-double-quantum filter experiment [66,67].

${ }^{13} \mathrm{C}$ NMR spectra were recorded using a single-pulse decoupling experiment both with and without nOe at $125.76 \mathrm{MHz}$ using a spectral width of $31446.54 \mathrm{~Hz}$, an acquisition time of $0.8 \mathrm{~s}, 32678$ points, $2052 \mathrm{scans}$, and a recycle delay of $0.1 \mathrm{~s}$. The non-decoupled ${ }^{13} \mathrm{C}$ NMR spectra with nOe were recorded with a spectral width of $39308.17 \mathrm{~Hz}$, a resolution of $0.9 \mathrm{~Hz}$, and 2048 scans, and the process was performed using the sinebell function and zero filling.

${ }^{1} \mathrm{H},{ }^{1} \mathrm{H}$-COSY spectra were obtained using a dqf-COSY pulse sequence with a data point matrix of $1024 \times 256$, a spectral width of $9384 \times 9384 \mathrm{~Hz}$, and a recycle delay of $1.5 \mathrm{~s}$. t-ROESY spectra were obtained using a data point matrix of $1024 \times 256$ with a spectral width of $6354 \times 6354 \mathrm{~Hz}$, mixture time of $1 \mathrm{~s}$, and a recycle delay of $1.5 \mathrm{~s}[66,67]$.

Mass spectra were recorded on an Agilent G1969 LC/MSD TOF spectrometer coupled to HPLC with electrospray ionization. 


\section{X-ray crystal structure analysis}

The crystals were mounted on a glass fiber and collected on an Enraf-Nonius CAD-4 diffractometer, a Kappa CCD with an area detector using $\mathrm{Mo} \mathrm{K} \alpha(\lambda=0.71073 \AA)$ radiation at $293 \mathrm{~K}$. Intensity data were collected and processed using CAD4 EXPRESS Software. The structures were solved using WinGX [68] by direct methods with SHELXS-97 [69] and refined by the full-matrix least-squares method on F2 with SHELXL-97. Note that in this report we use our crystallography results of compounds $\mathbf{1}, \mathbf{3}, \mathbf{5}, \mathbf{6}$, and 7 .

\section{Details of the calculations and computational methods}

The computational chemistry calculations were performed using the Gaussian 09 package [70], and molecular visualization was performed with ChemCraft 1.7 (2013) software [71]. Geometry optimization and natural bond orbital (NBO) analysis was performed for compounds $\mathbf{1}$ and $\mathbf{3}$ using density functional theory (DFT) with the long-range corrected $\omega \mathrm{B} 97 \mathrm{XD}$ functional $[72,73]$ and the $6-311++G(d, p)$ basis set. This basis set includes diffusion and polarization functions, and performs better for the description of molecular orbitals from geometry optimization and NBO analysis.

\section{General procedure for the synthesis of 2,4- diphenyl-3-azabicyclo[3.3.1]nonan-9-ones}

The compounds 1-2 were prepared following a previously reported method, and their physical and spectroscopic properties are in good agreement with the reported values [50-52].

The synthesis of 2,4-diphenyl-3-azabicyclo[3.3.1]nonan-9-one was performed by the following method. First, $5.10 \mathrm{mmol}$ of ketone, $10.2 \mathrm{mmol}$ of ammonium acetate, and $10.2 \mathrm{mmol}$ of benzaldehyde or $m$-nitrobenzaldehyde were added to a $100 \mathrm{~mL}$ flask, followed by addition of $30 \mathrm{~mL}$ of ethanol. Second, the mixture was stirred and heated to reflux, it was monitored by thin-layer chromatography, and was stopped when the reaction was completed. Next, the mixture was cooled, $30 \mathrm{~mL}$ of water was added, and the mixture was neutralized using aqueous $\mathrm{NaOH}$, followed by extraction using dichloromethane $(3 \times 25 \mathrm{~mL})$. Finally, the organic phases were combined and dried over $\mathrm{MgSO}_{4}$, and the solvent was removed. The compounds were purified by recrystallization in $2: 1$ acetone-methanol. Yields were $60-80 \%$.

The physical and spectroscopic properties of compounds 3-5 are in agreement with previous reports [53-56].

2,4-Bis(3-nitrophenyl)-3-azabicyclo[3.3.1] nonan-9-one (6). White solid, Yield: $73 \%$, by using the general procedure $5.10 \mathrm{mmol}$ of cyclohexanone and $10.2 \mathrm{mmol}$ of ammonium acetate, and $10.2 \mathrm{mmol}$ of $m$-nitrobenzaldehyde were added to the reaction. ESIMS-TOF: $m / z$ for $\mathrm{C}_{20} \mathrm{H}_{19} \mathrm{~N}_{3} \mathrm{O}_{5}[\mathrm{M}+\mathrm{H}]^{+}$ calcd: 382.1397, found: 382.1395; ${ }^{1} \mathrm{H} \mathrm{NMR}\left(500 \mathrm{MHz}, \mathrm{CDCl}_{3}\right)$ $\delta 8.41$ (s, 2H, H11, H17), 8.20 (d, $J=8.2 \mathrm{~Hz}, 2 \mathrm{H}, \mathrm{H} 13, \mathrm{H} 19)$, $7.92(\mathrm{~d}, J=7.6 \mathrm{~Hz}, 2 \mathrm{H}, \mathrm{H} 15, \mathrm{H} 21), 7.64$ ( t $, J=7.6 \mathrm{~Hz}, 2 \mathrm{H}$, H14, H20), 4.58 (d $J=1.9 \mathrm{~Hz}, 2 \mathrm{H}, \mathrm{H} 2, \mathrm{H} 4), 2.82$ ( dtt, $J=13.3$, 13.2, $6.2 \mathrm{~Hz}, 1 \mathrm{H}, \mathrm{H} 7 \mathrm{ax}$ ), 2.56 (d, $J=1.9 \mathrm{~Hz}, 2 \mathrm{H}, \mathrm{H} 1, \mathrm{H} 5), 1.86$ (dd, $J=13.6,6.2 \mathrm{~Hz}, 2 \mathrm{H}, \mathrm{H} 6 e c, \mathrm{H} 8 e c$ ), 1.78 (tt, $J=13.6,6.2$ Hz, 2H, H6ax, H8ax), 1.49 (dd, $J=13.2,6.2 \mathrm{~Hz}, 1 \mathrm{H}, \mathrm{H} 7 e c$ ); ${ }^{13} \mathrm{C}$ NMR (500 MHz, $\left.\mathrm{CDCl}_{3}\right) \delta 21.18$ (C7), 28.92 (C6, C8), 53.24 (C1, C5), 64.02 (C2-NH, C4-NH), 121.90 (C13, C19), 123.08 (C11, C17) 129.94 (C14, C20), 133.05 (C15, C21), 142.82 (C10, C16), 148.70 (C12-C18), $214.92(\mathrm{C}=\mathrm{O})$.

1-Methyl-2,4-bis(3-nitrophenyl)-3-azabicyclo[3.3.1]nonan-9one (7). Yellow solid, Yield: $72 \%$, by using the general procedure $5.10 \mathrm{mmol}$ of 2-methylcyclohexanone and $10.2 \mathrm{mmol}$ of ammonium acetate, and $10.2 \mathrm{mmol}$ of $m$-nitrobenzaldehyde were added to the reaction. ESIMS-TOF: $m / z$ for $\mathrm{C}_{21} \mathrm{H}_{21} \mathrm{~N}_{3} \mathrm{O}_{5}$ $[\mathrm{M}+\mathrm{H}]^{+}$calcd: 396.1553 , found: 396.1558; ${ }^{1} \mathrm{H}$ NMR $\left(500 \mathrm{MHz}, \mathrm{CDCl}_{3}\right) \delta 8.39$ (s, 1H, H11), 8.34 (s, 1H, H17), 8.19 (dd, $J=8.1,1.9 \mathrm{~Hz}, 2 \mathrm{H}, \mathrm{H} 13), 8.15$ (dd, $J=8.1,1.9 \mathrm{~Hz}, 2 \mathrm{H}$, H19), 7.94 (d, $J=7.5 \mathrm{~Hz}, 1 \mathrm{H}, \mathrm{H} 15), 7.58-7.63$ (m, 2H, H14, H20), 7.87 (d, $J=7.6 \mathrm{~Hz}, 1 \mathrm{H}, \mathrm{H} 21), 4.56$ (d, $J=2.3 \mathrm{~Hz}, 1 \mathrm{H}$, H4), 4.12 (s, 1H, H2), 3.11 (dtt, $J=13.4,13.2,6.3 \mathrm{~Hz}, 1 \mathrm{H}$, H7ax), 2.63 (dd, $J=2.9,2.3 \mathrm{~Hz}, 1 \mathrm{H}, \mathrm{H} 5$ ), 2.01 ( ddd, $J=13.6$, 5.6, $2.3 \mathrm{~Hz}, 1 \mathrm{H}, \mathrm{H} 8 e c$ ), 1.84 (ddd, $J=13.8,6.3,2.3 \mathrm{~Hz}, 1 \mathrm{H}$, H6ec), 1.76 ( tt, $J=13.4,6.3 \mathrm{~Hz}, \mathrm{H} 6 \mathrm{ax}), 1.46-1.45$ (m, 2H, $\mathrm{H} 7 e c, \mathrm{H} 8 \mathrm{ax}), 0.82$ (s, 3H, Me); ${ }^{13} \mathrm{C} \mathrm{NMR}\left(500 \mathrm{MHz}, \mathrm{CDCl}_{3}\right) \delta$ 20.25 (Me), 21.45 (C7), 29.01 (C6), 36.74 (C8), 50.55 (C1), 53.68 (C5), 70.42 (C2), 121.77 (C17), 122.92 (C19), 123.35 (C13), 123.85 (C11), 129.42 (C20), 129.86 (C14), 133.03 (C21), 135.21 (C15), 141.37 (C16) 142.93 (C10), 148.26 (C18), $148.61(\mathrm{C} 12), 215.46(\mathrm{C}=\mathrm{O})$.

1,5-Dimethyl-2,4-bis(3-nitrophenyl)-3-azabicyclo[3.3.1]nonan-9-one (8). White solid, Yield: $64 \%$, by using the general procedure $5.10 \mathrm{mmol}$ of 2,6-dimethylcyclohexanone and $10.2 \mathrm{mmol}$ of ammonium acetate, and $10.2 \mathrm{mmol}$ of $m$-nitrobenzaldehyde were added to the reaction. ESIMS-TOF: $m / z$ for $\mathrm{C}_{22} \mathrm{H}_{23} \mathrm{~N}_{3} \mathrm{O}_{5}[\mathrm{M}+\mathrm{H}]^{+}$calcd: 410.1710 , found: 410.1713; ${ }^{1} \mathrm{H} \mathrm{NMR}\left(500 \mathrm{MHz}, \mathrm{CDCl}_{3}\right) \delta 7.53(\mathrm{~d}, J=7.4 \mathrm{~Hz}$, 4H, H11, H15, H17, H21), 7.36 (t, $J=7.4$ Hz, 4H, H12, H14, H18, H20), 7.30 (t, $J=7.4$ Hz, 2H, H13, H19), 3.35 (s, 2H, H2, H4), 3.03 ( dtt, $J=13.8,13.2,6.8 \mathrm{~Hz}, 1 \mathrm{H}, \mathrm{H} 7 a x$ ), 1.61 (dd, $J=$ 13.8, $6.8 \mathrm{~Hz}, 2 \mathrm{H}, \mathrm{H} 6 e c, \mathrm{H} 8 \mathrm{ec}$ ), 1.11 (H6ax ) 0.81 (H8ax), 0.69 (s $6 \mathrm{H}, \mathrm{Me}$ ); ${ }^{13} \mathrm{C} \mathrm{NMR}\left(500 \mathrm{MHz}, \mathrm{CDCl}_{3}\right) \delta 20.26(\mathrm{Me}), 21.10$ (C7), 36.40 (C6, C8), 50.15 (C1, C5), 70.22 (C2-NH, C4-NH), 123.35 (C13, C19), 123.85 (C11, C17), 129.42 (C14, 20), 135.21 (C15, C21), 142.93 (C10, C16), 148.61 (C12, C18), $215.46(\mathrm{C}=\mathrm{O})$. 


\section{Supporting Information}

Crystallographic data of the structures reported in this paper have been deposited with the Cambridge Crystallographic Data Centre with supplementary publication numbers CCDC 928314 (1), 928315 (6), and 933224 (7). These data can be obtained free of charge from The Cambridge Crystallographic Data Centre via $\mathrm{http} / / /$ www.ccdc.cam.ac.uk/data_request/cif.

\section{Supporting Information File 1}

Additional schemes, figures, theoretical, spectra, and crystallographic data.

[http://www.beilstein-journals.org/bjoc/content/ supplementary/1860-5397-11-213-S1.pdf]

\section{Acknowledgements}

The authors acknowledge financial support from Consejo Nacional de Ciencia y Tecnología (Research Grant No. 56604). G-M Cesar would like to thank CONACyT for grant scholarships. We thank I.Q. Geiser Cuéllar for the mass spectra, Q. Teresa Cortés for the NMR spectra, and Marco A. Leyva for assistance with determination of the X-ray diffraction structures. The authors express their gratitude to Dra. Rosa Santillan for her critical reading.

\section{References}

1. Carey, F. A.; Sundberg, R. J. Advanced Organic Chemistry. Part A: Structure and Mechanisms, 5th ed.; Springer: New York, 2007.

2. Orchin, M.; Macomber, R. S.; Pinhas, A. R.; Wilson, R. M. The Vocabulary and Concepts of Organic Chemistry, 2nd ed.; Wiley-Interscience: New Jersey, 2005. doi:10.1002/0471713740

3. Gorenstein, D. G. Chem. Rev. 1987, 87, 1047. doi:10.1021/cr00081a009

4. Juaristi, E. Conformational Behavior of Six-Membered Rings; VCH Publishers: New York, 1995

5. Kirby, J. A. Stereoelectronic Effects; Oxford University Press, 1996

6. Thatcher, G. R. J. The Anomeric Effect and Associated Stereoelectronic Effects; ACS Symposium Series 539; American Chemical Society: Washington DC., 1993.

7. Juaristi, E.; Cuevas, G. Tetrahedron 1992, 48, 5019. doi:10.1016/S0040-4020(01)90118-8

8. Perlin, A. S.; Casu, B. Tetrahedron Lett. 1969, 34, 2921. doi:10.1016/S0040-4039(01)88308-8

9. Wolfe, S.; Pinto, B. M.; Varma, V.; Leung, R. Y. N. Can. J. Chem. 1990, 68, 1051. doi:10.1139/v90-164

10. Perrin, L. C. Acc. Chem. Res. 2002, 35, 28. doi:10.1021/ar970169q

11. Guerrero-Álvares, J. A.; Mas-Ku, W. P.; Garcías-Morales, C.; Ariza-Castolo, A. Magn. Reson. Chem. 2010, 48, 356 doi:10.1002/mrc.2592

12. Silla, J. M.; Freitas, M. P.; Cormanich, R. A.; Rittner, R. J. Org. Chem. 2014, 79, 6385. doi:10.1021/jo501025a

13. Exner, O.; Böhm, S. New J. Chem. 2008, 32, 1449. doi:10.1039/b718430a
14. Lehn, J. M.; Wipff, G. J. Am. Chem. Soc. 1976, 98, 7498. doi:10.1021/ja00440a007

15. Laube, T. Acc. Chem. Res. 1995, 28, 399. doi:10.1021/ar00058a001

16. Olah, G. A.; Reddy, V. P.; Prakash, G. K. S. Chem. Rev. 1992, 92, 69. doi:10.1021/cr00009a003

17. Olah, G. A.; Prakash, G. K. S.; Shih, J. G.; Krishnamurthy, V. V.; Mateescu, G. D.; Liang, G.; Sipos, G.; Buss, V.; Gund, T. M.; v. R. Schleyer, P. J. Am. Chem. Soc. 1985, 107, 2764. doi:10.1021/ja00295a032

18. v. R. Schleyer, P.; Lenoir, D.; Mison, P.; Liang, G.; Prakash, G. K. S.; Olah, G. A. J. Am. Chem. Soc. 1980, 102, 683. doi:10.1021/ja00522a041

19. Giese, B.; Dupuis, J. Angew. Chem., Int. Ed. Engl. 1983, 22, 622. doi:10.1002/anie.198306221

20. Adlington, R. M.; Baldwin, J. E.; Basak, A.; Kozyrod, R. P. Chem. Commun. 1983, 944. doi:10.1039/c39830000944

21. Praly, J.-P. Tetrahedron Lett. 1983, 24, 3075. doi:10.1016/S0040-4039(00)88099-5

22. Alabugin, I. V.; Gilmore, K. M.; Peterson, P. W. Wiley Interdiscip. Rev.: Comput. Mol. Sci. 2011, 1, 109. doi: $10.1002 / w c m s .6$

23. Lamber, J. B.; Zhao, Y.; Emblidge, R. W.; Salvador, L. A.; Liu, X.; So, J.-H.; Chelius, E. C. Acc. Chem. Res. 1999, 32, 183. doi:10.1021/ar970296m

24. Shiner, V. J., Jr.; Ensinger, M. W.; Rutkowske, R. D. J. Am. Chem. Soc. 1987, 109, 804. doi:10.1021/ja00237a027

25. Lambert, J. B.; So, J.-H.; Salvador, L. A. Tetrahedron Lett. 1990, 31, 3841. doi:10.1016/S0040-4039(00)97483-5

26. Lambert, J. B.; Salvador, L. A.; So, J. H. Organometallics 1993, 12, 697. doi:10.1021/om00027a020

27. Lambert, J. B.; Ciro, S. M. J. Org. Chem. 1996, 61, 1940. doi:10.1021/jo951643d

28. Kleinpeter, E.; Koch, A.; Pihlaja, K. Tetrahedron 2005, 61, 7349. doi:10.1016/j.tet.2005.05.083

29. Juaristi, E.; Rosquete-Pina, G. A.; Vázquez-Hernández, M.; Mota, A. J. Pure Appl. Chem. 2003, 75, 589. doi:10.1351/pac200375050589

30. Bailey, W. F.; Rivera, A. D.; Rossi, K. Tetrahedron Lett. 1988, 29 , 5621. doi:10.1016/S0040-4039(00)80828-X

31. Juaristi, E.; Cuevas, G. Tetrahedron Lett. 1992, 33, 1847. doi:10.1016/S0040-4039(00)74158-X

32. Juaristi, E.; Cuevas, G.; Vela, A. J. Am. Chem. Soc. 1994, 116, 5796. doi:10.1021/ja00092a034

33. Cai, J.; Davies, A. G.; Schiesser, C. H. J. Chem. Soc., Perkin Trans. 2 1994, 1151. doi:10.1039/p29940001151

34. Garcías-Morales, C.; Martínez-Salas, S. H.; Ariza-Castolo, A. Tetrahedron Lett. 2012, 53, 3310. doi:10.1016/j.tetlet.2012.04.077

35. Cuevas, G.; Juaristi, E.; Vela, A. J. Phys. Chem. A 1999, 103, 932. doi:10.1021/jp983664s

36. Anderson, J. E.; Cai, J.; Davies, A. G. J. Chem. Soc., Perkin Trans. 2 1997, 2633. doi:10.1039/a705034h

37. Alabugin, I. V.; Manoharan, M.; Zeidan, T. A. J. Am. Chem. Soc. 2003, 125, 14014. doi:10.1021/ja037304g

38. Alabugin, I. V. J. Org. Chem. 2000, 65, 3910. doi:10.1021/jo991622+

39. Anderson, J. E.; Bloodworth, A. J.; Cai, J.; Davies, A. G.; Tallant, N. A. J. Chem. Soc., Chem. Commun. 1992, 1689. doi:10.1039/c39920001689

40. Anderson, J. E.; Bloodworth, A. J.; Cai, J.; Davies, A. G.; Schiesser, C. H. J. Chem. Soc., Perkin Trans. 2 1993, 601. doi:10.1039/p29930000601 
41. Pandey, A. K.; Yap, G. P. A.; Zondlo, N. J. J. Org. Chem. 2014, 79, 4174. doi:10.1021/j0500367d

42. Juaristi, E.; Cuevas, G. Acc. Chem. Res. 2007, 40, 961. doi:10.1021/ar6000186

43. Cuevas, G.; Juaristi, E. J. Am. Chem. Soc. 2002, 124, 13088. doi:10.1021/ja020317u

44. Wedel, T.; Müller, M.; Podlech, J.; Goesmann, H.; Feldmann, C. Chem. - Eur. J. 2007, 13, 4273. doi:10.1002/chem.200601468

45. García de la Vega, J. M.; San Fabián, J. Analysis of contributions to spin-spin coupling constants by the natural J-coupling method. In High Resolution NMR spectroscopy: understanding molecules and their electronic structures; Contreras, R. H., Ed.; Elsevier, 2013; Chapter 6. doi:10.1016/B978-0-444-59411-2.00006-X

46. Merino, P.; Tejero, T. Synlett 2011, 22, 1965. doi:10.1055/s-0030-1260979

47. Touré, B. B.; Hall, D. G. Chem. Rev. 2009, 109, 4439. doi:10.1021/cr800296p

48. Nielsen, M.; Worgull, D.; Zweifel, T.; Gschwend, B.; Bertelsen, S.; Jørgensen, K. A. Chem. Commun. 2011, 47, 632. doi:10.1039/C0CC02417A

49. Mannich, C.; Krösche, W. Arch. Pharm. 1912, 250, 647. doi:10.1002/ardp.19122500151

50. Połoński, T.; Pham, M.; Milewska, M. J.; Gdaniec, M. J. Org. Chem. 1996, 61, 3766. doi:10.1021/jo9600159

51. Venkateswaramoorthi, R.; Xavier, J. J. F.; Krishnasamy, K.; Saleem, H. J. Mol. Struct. 2012, 1012, 119. doi:10.1016/j.molstruc.2011.12.045

52. Takajo, T.; Kambe, S. Synthesis 1981, 151. doi:10.1055/s-1981-29372

53. Parthiban, P.; Subalakshmi, V.; Balasubramanian, K.; Islam, M. N.; Choi, J. S.; Jeong, Y. T. Bioorg. Med. Chem. Lett. 2011, 21, 2287. doi:10.1016/j.bmcl.2011.02.103

54. Parthiban, P.; Rathika, P.; Ramkumar, V.; Son, S. M.; Jeong, Y. T. Bioorg. Med. Chem. Lett. 2010, 20, 1642. doi:10.1016/j.bmcl.2010.01.048

55. Park, D. H.; Jeong, Y. T.; Parthiban, P. J. Mol. Struct. 2011, 1005, 31. doi:10.1016/j.molstruc.2011.08.006

56. Pham, M.; Gdaniec, M.; Połoński, T. J. Org. Chem. 1998, 63, 3731. doi:10.1021/jo9800457

57. Hoffmann, R. W. Chem. Rev. 1989, 89, 1841. doi:10.1021/cr00098a009

58. Baldwin, J. E.; Lusch, M. J. Tetrahedron 1982, 38, 2939. doi:10.1016/0040-4020(82)85023-0

59. Gilmore, K.; Alabugin, I. V. Chem. Rev. 2011, 111, 6513. doi:10.1021/cr200164y

60. Navarro-Vázquez, A.; Cobas, J. C.; Sardina, F. J.; Casanueva, J.; Díez, E. J. Chem. Inf. Comput. Sci. 2004, 44, 1680. doi:10.1021/ci049913t

61. Omarov, T. T.; Amanzholov, I. A. Vestn. Akad. Nauk Kaz. SSR 1986, 82.

62. Omarov, T. T.; Buranbaev, M. Z.; Gubin, A. I.; Suleimanov, K. T.; Gladii, Y. P. Zh. Obshch. Khim. 1984, 54, 440.

63. Suleimanov, K.; Shalamov, A. E.; Omarov, T. T.; Buranbaev, M. Z. Vestn. Akad. Nauk Kaz. SSR 1977, 61.

64. Contreras, R. H.; Peralta, J. E. Prog. Nucl. Magn. Reson. Spectrosc. 2000, 37, 321. doi:10.1016/S0079-6565(00)00027-3

65. Contreras, R. H.; Suardíaz, R.; Pérez, C.; Crespo-Otero, R.; San Fabián, J.; García de la Vega, J. M. Int. J. Quantum Chem. 2010, 110, 532. doi:10.1002/qua.22136

66. Freeman, R. A Handbook of Nuclear Magnetic Resonance; Longman Scientific Technical: Harlow, 1987; p 145.
67. Berger, S.; Braun, S. 200 and More NMR Experiments, A Practical Course, 2nd ed.; Wiley-VCH, 1998; p 207.

68. Farrugia, L. J. J. Appl. Crystallogr. 1999, 32, 837. doi:10.1107/S0021889899006020

69. Sheldrick, G. M. Acta Crystallogr. 2008, A64, 112. doi:10.1107/S0108767307043930

70. Gaussian 09, Revision D.01; Gaussian, Inc.: Wallingford, CT, 2013.

71. Chemcraft, Version 1.7 (Build 382); Bluesnap, Inc.: Waltham, Massachusetts, 2013, http://www.chemcraftprog.com.

72. Chai, J.-D.; Head-Gordon, M. Phys. Chem. Chem. Phys. 2008, 10, 6615. doi:10.1039/b810189b

73. Chai, J.-D.; Head-Gordon, M. J. Chem. Phys. 2008, 128, 084106. doi:10.1063/1.2834918

\section{License and Terms}

This is an Open Access article under the terms of the Creative Commons Attribution License

(http://creativecommons.org/licenses/by/2.0), which permits unrestricted use, distribution, and reproduction in any medium, provided the original work is properly cited.

The license is subject to the Beilstein Journal of Organic Chemistry terms and conditions: (http://www.beilstein-journals.org/bjoc)

The definitive version of this article is the electronic one which can be found at: doi:10.3762/bjoc. 11.213 